\title{
Discharge Coefficient for V-Notch Broad Crested Side Weir Side Weir
}

\author{
Amal Abd Al-Ghnai Yahya \\ Water Resource Dept. College of Engineering University of Mosul
}

\begin{abstract}
In this paper the hydraulic characteristics of $V$-notch broad crested side weir have been experimentally studied. Sixteen $V$-notch broad crest weirs were constructed with six apex angles $\left(\theta=30^{\circ}, 45^{\circ}, 60^{\circ}, 90^{\circ}, 120^{\circ}\right.$, and $\left.150^{\circ}\right)$ and the apex height change three times $(p=5,10,15 \mathrm{~cm})$ for the first forth angles and change two times for the last two angles $(p=10,15 \mathrm{~cm})$, each model can be tested by changing flow in the main channel several times and from the analysis of experimental results it was found that the coefficient of discharge $(\mathrm{Cd})$ for the $V$-notch broad crested weir is depend on the hydraulic and geometric characteristics of channel and weir, and from the hydraulic characteristics of the main channel it was found that the coefficient of discharge (Cd) directly proportional to the main channel Froude number before side channel, and a maximum value of $(\mathrm{Cd})$ can be reached for a larger acute $V$-notch angle, but a maximum value of $(\mathrm{Cd})$ can be reached for the smaller obtuse $\mathrm{V}$-notch angle. Also from the hydraulic and geometric effect for both channel and weir it is found that (Cd) inversely proportional with $\left(\mathrm{y}_{1} / \mathrm{p}\right)$ and directly proportional with $\left(\mathrm{y}_{1} / \mathrm{h} \& \mathrm{p} / \mathrm{h}\right)$ and a maximum (Cd ) can be reached maximum for both acute and obtuse $V$-notch angle. Suitable equations for discharge coefficient are obtained for different apex angle, then the predicated discharge coefficient from the equations were plotted against the calculated value with coefficient of determination $\left(R^{2}=0.9\right)$ and it was found to be good.
\end{abstract}

$$
\text { معامل التصريف للهدارات الجاتبية ذات الحافة العريضة بفتحة مثلثة }
$$

في هذا البحث تم دراسة الخصائص الهيدروليكية لهدار جانبي عريض الحافة بفتحة مثلثة وضع في مأخذ قتاة

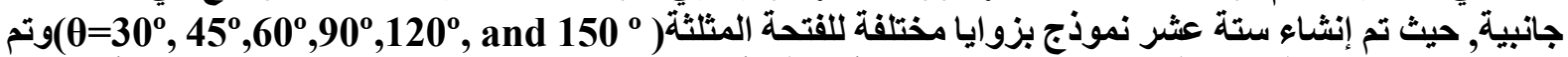

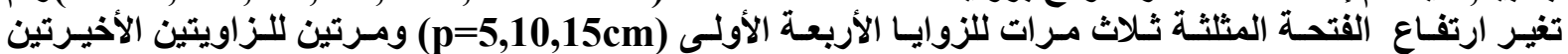
(p=10,15cm)

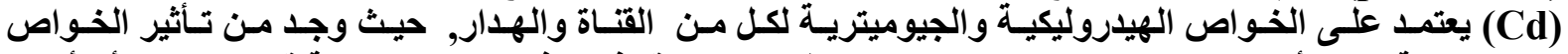

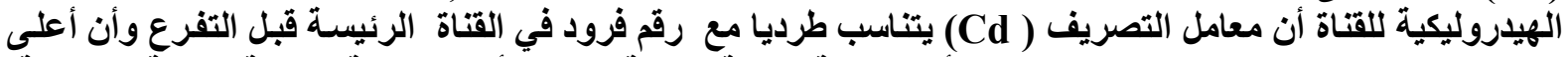

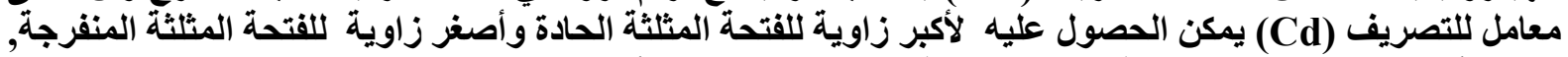

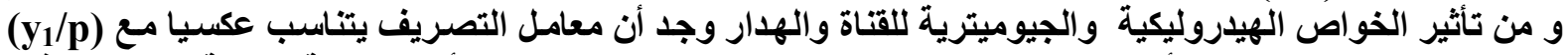

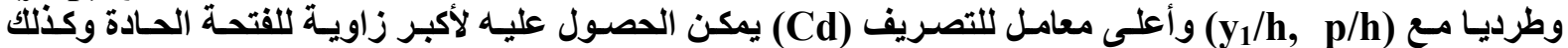

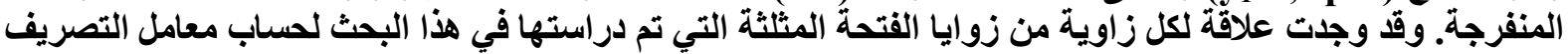

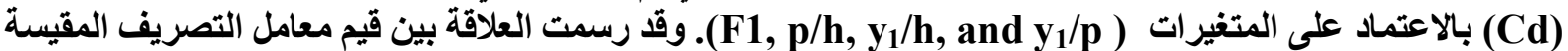

$$
\text { والمحسوبة ولوحظ تقارب جيا مع خط التوافث حيث بلغ معامل التحديد (Cd) (R2=0.9). }
$$




\section{Introduction:}

A broad crested weir is an over flow structure with a horizontal crest above which the stream lines are practically straight and parallel. Broad crested weirs can have a variety of cross sections in control sections, depending on the requirements. The simplest type is a square edged weir with a rectangular cross section [7]. A side broad crested weir is a fixed structure installed at the side of the main channel and used as a standard discharge device to control the flow depth and discharge. Estimation of discharge over the side weir is still an important issue and an on-going problem in the area of water measurement. The normal side weirs may be of different shape (i.e., rectangular, triangular, trapezoidal etc.). Further side weirs may be made sharp or broad crested [6]. Most pervious research works for side weir carried out in channel with rectangular cross section, the sharp and broad crested rectangular side weir have been studied extensively by many investigators $[2,4,5,6,7,8]$. It is obvious that almost all investigators have studied hydraulic characteristics of rectangular and triangular sharp crested side weir and less attention has been given to the behavior of flow over V-notch broad crested side weirs ${ }^{[6]}$. In this paper, experiments were carried on a Vnotch broad crested side weir with apex angles of $\left(\theta=30^{\circ}, 45^{\circ}, 60^{\circ}, 90^{\circ}, 120^{\circ}\right.$, and $\left.150^{\circ}\right)$ with different height of the apex for each angle. The experimental results were presented to validate a general expression for the estimation of discharge coefficient in terms of both hydraulic and geometrical parameters.

\section{Experimental set up:}

The experimental work was conducted at the Hydraulics Laboratory of Water Resource Engineering at the University of Mosul, Mosul, Iraq, using a long horizontal tilting main channel of (10)m long and a cross-section of $(0.3) \mathrm{m}$ width and $(0.45) \mathrm{m}$ height. The side channel was constructed perpendicular to the main channel at a distance (4.6)m upstream the main channel, the length of side channel is (2)m with cross section of $(0.15) \mathrm{m}$ width and (0.3)m height and zero slope. The main channel consisted of toughened glass walls, and the side channel consisted of plastic walls and both of a stainless steel floor. Three movable carriages with point gauges were mounted on brass rails at the top of the channel sides as shown in figure (1). Sixteen V-notch broad crested weirs models were made from wood of $(0.3) \mathrm{m}$ length and $(0.2) \mathrm{m}$ height . In these models, a V-notch of six different angles, with three different apex height, details of the models are shown in figure (2), and table (1). The $\mathrm{V}$-notch broad crested weir was installed at the upstream end of the side channel. For discharge measurement, a full width thin plate sharp crested rectangular weir (10)cm height fixed at the tail end of the main channel section manufactured according to British standard 1965 [3] ,the head over the weir was measured two times, first by locking the inlet of the side channel and the second time by the opening the inlet of the side channel to determine the discharge in the main channel before and after side channel $\mathrm{Q}_{1} \& \mathrm{Q}_{2}$ respectively, the head over the weir was measured with a precision point gauge whose least count was $(0.1) \mathrm{mm}$.

\section{Evaluation of discharge :}

The basic equation of V-notch broad crested weir used to evaluate the discharge over the side weir is:

$$
\mathrm{Q}_{\text {the }}=\mathrm{Cd}\left(8 / 15 \sqrt{2 g} \tan (\theta / 2) \mathrm{h}^{2.5}\right)
$$

In which: $\mathrm{Q}_{\text {the }}=$ theoretical discharge over side weir $\mathrm{m}^{3} / \mathrm{sec}, \mathrm{Cd}=$ coefficient of discharge, $\mathrm{h}=$ head of water upstream broad crested weir $\mathrm{m}, \mathrm{g}=$ acceleration due to gravity $\mathrm{m} / \mathrm{sec}^{2}$, $\theta=$ apex V-notch angle in degree. 
The actual discharge over the side weir computed by the following equations:

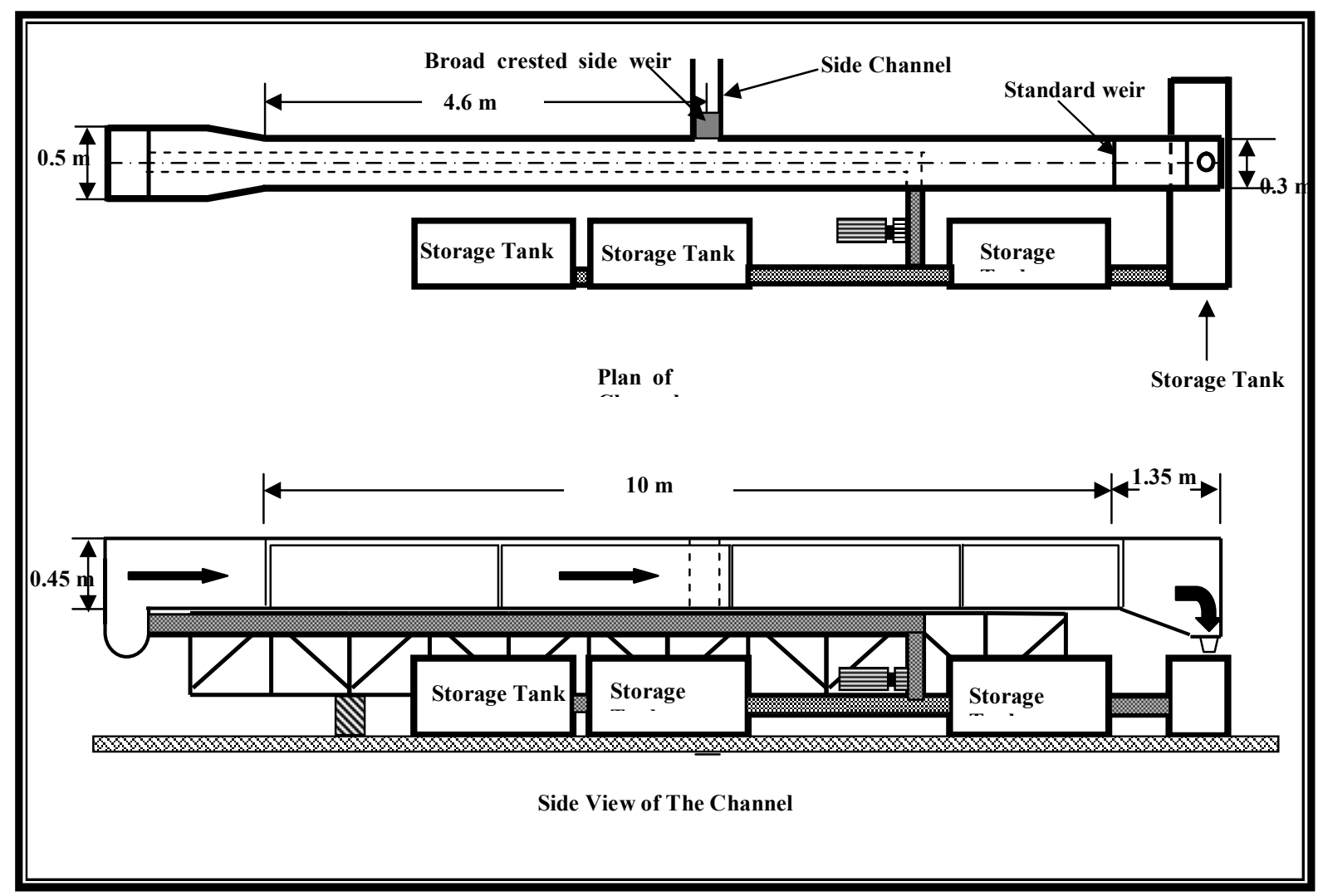

Fig. (1) Channel Cross Section

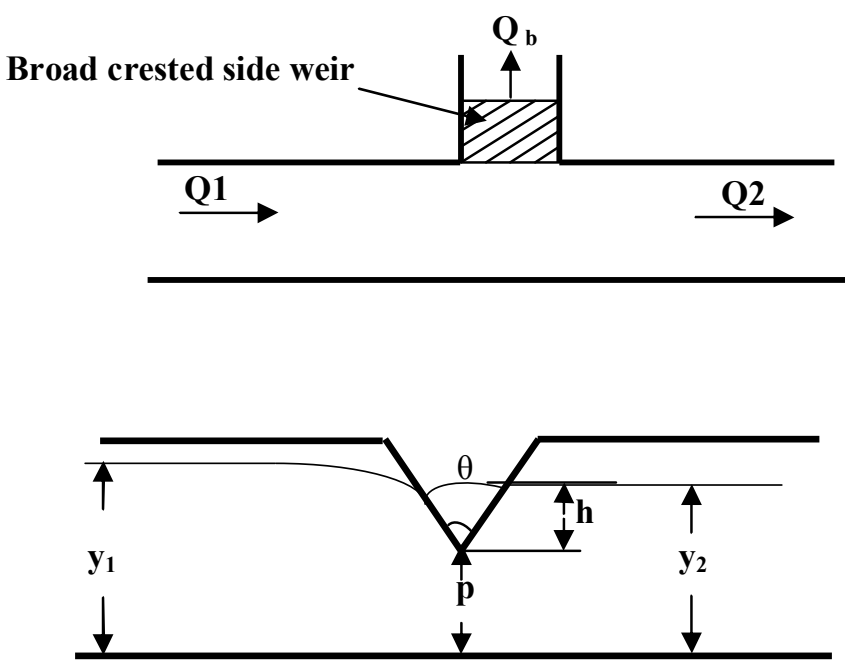

Fig. (2) Definition Sketch 
Table 1: Details of weir model investigated

\begin{tabular}{|c|c|c|c|}
\hline Model No. & Run No. & $\begin{array}{c}\text { Apex Angle } \\
\text { (Degree) }\end{array}$ & $\begin{array}{c}\text { Apex Height } \\
(\mathrm{cm})\end{array}$ \\
\hline 1 & $1-5$ & 30 & 5 \\
\hline 2 & $6-11$ & 30 & 10 \\
\hline 3 & $12-17$ & 30 & 15 \\
\hline 4 & $18-23$ & 45 & 5 \\
\hline 5 & $24-29$ & 45 & 10 \\
\hline 6 & $30-35$ & 45 & 15 \\
\hline 7 & $36-41$ & 60 & 5 \\
\hline 8 & $42-47$ & 60 & 10 \\
\hline 9 & $48-53$ & 60 & 15 \\
\hline 10 & $54-59$ & 90 & 5 \\
\hline 11 & $60-65$ & 90 & 10 \\
\hline 12 & $66-71$ & 90 & 15 \\
\hline 13 & $72-77$ & 120 & 10 \\
\hline 14 & $78-83$ & 120 & 15 \\
\hline 15 & $84-89$ & 150 & 10 \\
\hline 16 & $90-95$ & 150 & 15 \\
\hline
\end{tabular}

$\mathrm{Q}_{\mathrm{b}}=\left(\mathrm{Q}_{1}-\mathrm{Q}_{2}\right)$

In which: $\mathrm{Q}_{\mathrm{b}}=$ actual discharge over side weir, $\mathrm{Q}_{1}=$ discharge in main channel before side channel, $\mathrm{Q}_{2}=$ discharge in main channel after side channel.

Based on the equation determine by $\mathrm{Al}$ Omari ${ }^{[1]}$, the discharge in the main channel before and after side channel can be found as follows:

$\mathrm{Q}_{1}=0.57988 \mathrm{~h}_{1}{ }^{1.5}$

$\mathrm{h}_{1}=$ head of water in main channel upstream standard weir before side channel.

$\mathrm{Q}_{2}=0.57988 \mathrm{~h}_{2}{ }^{1.5}$

$\mathrm{h}_{2}=$ head of water in main channel upstream standard weir after side channel.

\section{Dimensional analysis:}

For flow over triangular broad crested weir, the variables involved are

$\mathrm{Cd}=f\left(\mu, \sigma, \rho, \mathrm{g}, \mathrm{p}, \theta, \mathrm{h}, \mathrm{y}_{1}, \mathrm{Q}_{1}\right)$

In which: $\rho=$ relative density of water, $\mu=$ kinematics viscosity of water,$\sigma=$ coefficient of surface tension of water, $\mathrm{p}=$ apex height, $\mathrm{y}_{1}=$ upstream depth of flow in the main channel before side channel.

By using the dimensional analysis based on discharge equations, the following functional relation is obtained: 
$\mathrm{Cd}=f\left(\mathrm{~F} 1, \mathrm{Re}, \mathrm{We}, \mathrm{p} / \mathrm{h}, \mathrm{y}_{1} / \mathrm{h}, \mathrm{y}_{1} / \mathrm{p}, \theta\right)$

In which: $\mathrm{F} 1=\mathrm{V}_{1} / \sqrt{g y_{1}}=$ Froude number in the main channel, $\mathrm{V} 1=$ velocity of flow before side channel $\mathrm{m} / \mathrm{sec}, \mathrm{Re}=$ Reynolds number, We=Weber number.

By assuming that the crest of the weir is smooth, Reynolds number is large enough to neglect viscous effect and Weber number is large enough to neglect surface tension effects [2]. There fore equation (6) can be reduced to :

$\mathrm{Cd}=f\left(\mathrm{~F} 1, \mathrm{p} / \mathrm{h}, \mathrm{y}_{1} / \mathrm{h}, \mathrm{y}_{1} / \mathrm{p}, \theta\right)$

\section{Analysis of Results and discussion:}

The discharge coefficient for $\mathrm{V}$-notch broad crested side weir was calculated for six apex angle $\left(\theta=30^{\circ}, 45^{\circ}, 60^{\circ}, 90^{\circ}, 120^{\circ}\right.$, and $\left.150^{\circ}\right)$. It is found that $\left(\mathrm{F} 1, \mathrm{p} / \mathrm{h}, \mathrm{y}_{1} / \mathrm{h}\right.$, and $\left.\mathrm{y}_{1} / \mathrm{p}\right)$ has a significant effect on $(\mathrm{Cd})$ as follows:

1- The relations between discharge coefficient $(\mathrm{Cd})$ and Froude number F1 is plotted in figures ( 3 and 4$)$, and from these figures it is found that for each V-notch angle, $(\mathrm{Cd})$ increases as F1 increase, and from figure (3) when V-notch is acute a maximum value of $(\mathrm{Cd})$ can be reached for acute angle $\left(90^{\circ}\right)$ and decrease gradually as acute angle decrease $\left(60^{\circ}, 45^{\circ}, 30^{\circ}\right)$. While from figure (4) when $\mathrm{V}$-notch is obtuse a maximum (Cd) can be reached for an obtuse angle $\left(150^{\circ}\right)$ and decrease as obtuse angle decrease to $\left(120^{\circ}\right)$.

2- The relation between discharge coefficient $(\mathrm{Cd})$ and the parameter $\left(\mathrm{y}_{1} / \mathrm{p}\right)$ for all $\mathrm{V}$ notch angles, is plotted in figures (5 and 6), the figures shows that $(\mathrm{Cd})$ decreases as $\left(\mathrm{y}_{1} / \mathrm{p}\right)$ increase, and maximum $(\mathrm{Cd})$ can be reached at a maximum $\mathrm{V}$-notch angle, and (Cd) decrease when the angle decrease for both acute and obtuse V-notch.

3- Figures (7) to (10) show the relation between discharge coefficient $(\mathrm{Cd})$ with the parameters $\left(\mathrm{y}_{1} / \mathrm{h}\right.$, and $\left.\mathrm{p} / \mathrm{h}\right)$ for all $\mathrm{V}$-notch angles, the figures show that $(\mathrm{Cd})$ increases as $\left(\mathrm{y}_{1} / \mathrm{h}\right.$, and $\left.\mathrm{p} / \mathrm{h}\right)$ increase, a maximum $(\mathrm{Cd})$ can be reached at the maximum $\mathrm{V}$-notch angle, and $(\mathrm{Cd})$ decrease as the angle decrease for both acute and obtuse V-notch.

4- From the analysis of experimental results, table (2) shows the range of values of discharge coefficient $(\mathrm{Cd})$ for each degree of $\mathrm{V}$-notch of broad crested side weirs that be studied.

A mathematical models is developed by multiple nonlinear regression analysis using the experimental data for various values of apex angle which is used to correlate the value of discharge coefficient $(\mathrm{Cd})$ to both hydraulic and geometrical parameters $\left(\mathrm{F} 1, \mathrm{p} / \mathrm{h}, \mathrm{y}_{\mathrm{l}} / \mathrm{h}\right.$, and $\left.\mathrm{y}_{1} / \mathrm{p}\right)$.The following equations fits the data for each apex angle with the coefficient of determination $\left(\mathrm{R}^{2}=0.88,0.81,0.68,0.52,0.98,0.999\right)$ for the following angles respectively:

$$
\begin{array}{lcc}
C d=1-0.2576(F 1)-0.09(\mathrm{p} / \mathrm{h})-0.413\left(\mathrm{y}_{1} / \mathrm{h}\right)-0.9185\left(\mathrm{y}_{1} / \mathrm{p}\right) & \text { for } \theta=30^{\circ} & \text {----- }(8) \\
\mathrm{Cd}=1-0.3718(\mathrm{~F} 1)-0.2682(\mathrm{p} / \mathrm{h})-0.285\left(\mathrm{y}_{1} / \mathrm{h}\right)-0.8351\left(\mathrm{y}_{1} / \mathrm{p}\right) & \text { for } \theta=45^{\circ} & \text {---- }(9) \\
\mathrm{Cd}=1-0.1042(\mathrm{~F} 1)+0.9414(\mathrm{p} / \mathrm{h})-0.9522\left(\mathrm{y}_{1} / \mathrm{h}\right)-0.6361\left(\mathrm{y}_{1} / \mathrm{p}\right) & \text { for } \theta=60^{\circ} & \text {---- }(10) \\
C d=1-0.5842(\mathrm{~F} 1)-0.2091(\mathrm{p} / \mathrm{h})+0.1482\left(\mathrm{y}_{1} / \mathrm{h}\right)-0.9318\left(\mathrm{y}_{1} / \mathrm{p}\right) & \text { for } \theta=90^{\circ} & \text {---- }(11) \\
C d=1+0.456(\mathrm{~F} 1)+0.6448(\mathrm{p} / \mathrm{h})-0.6896\left(\mathrm{y}_{1} / \mathrm{h}\right)-0.832\left(\mathrm{y}_{1} / \mathrm{p}\right) & \text { for } \theta=120^{\circ} & \text {---- }(12) \\
108 & &
\end{array}
$$


$\mathrm{Cd}=1+0.7275(\mathrm{~F} 1)+0.7247(\mathrm{p} / \mathrm{h})-0.7493\left(\mathrm{y}_{1} / \mathrm{h}\right)-0.9133\left(\mathrm{y}_{1} / \mathrm{p}\right) \quad$ for $\theta=150^{\circ}$

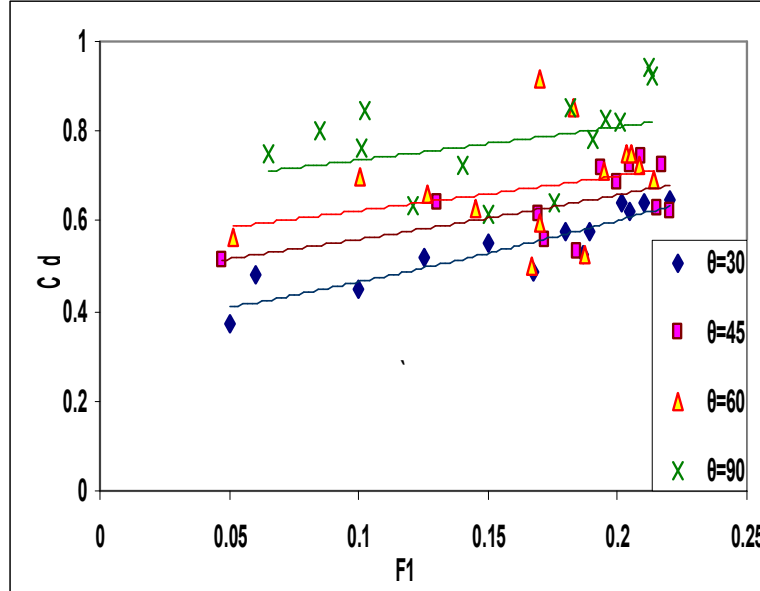

Fig(3) Relation between discharge coefficient (Cd)\& Froude number ( F1) for acute V-notch

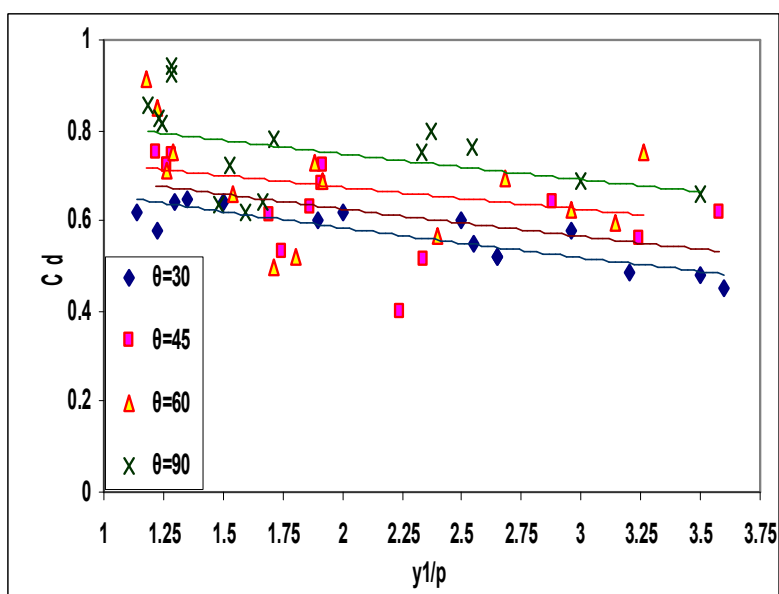

Fig(5) Relation between discharge coefficient (Cd) \& y1/p for acute V-notch

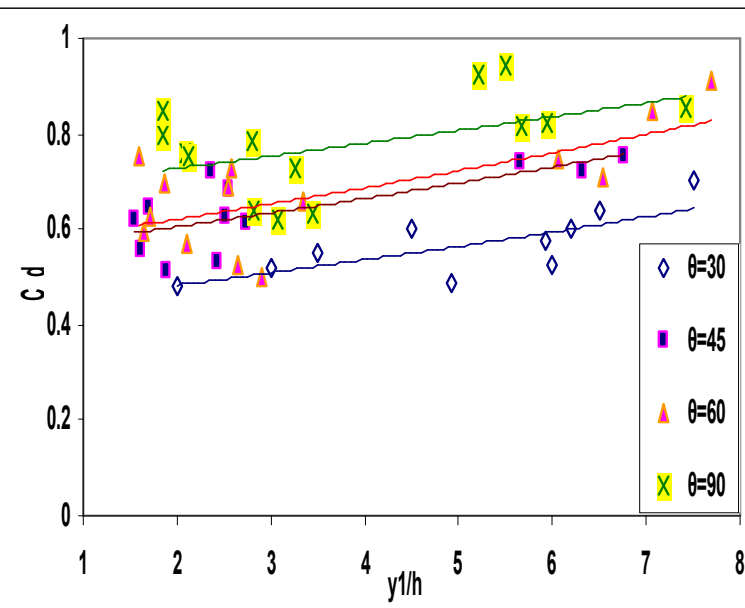

Fig(7) Relation between discharge coefficient (Cd) \& y1/h for acute V-notch

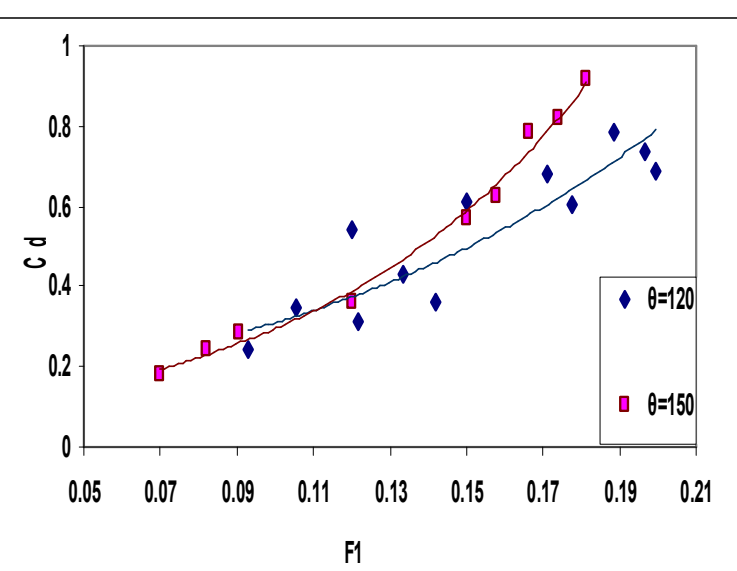

Fig(4) Relation between discharge coefficient (Cd)\& Froude number (F1) for obtuse V-notch

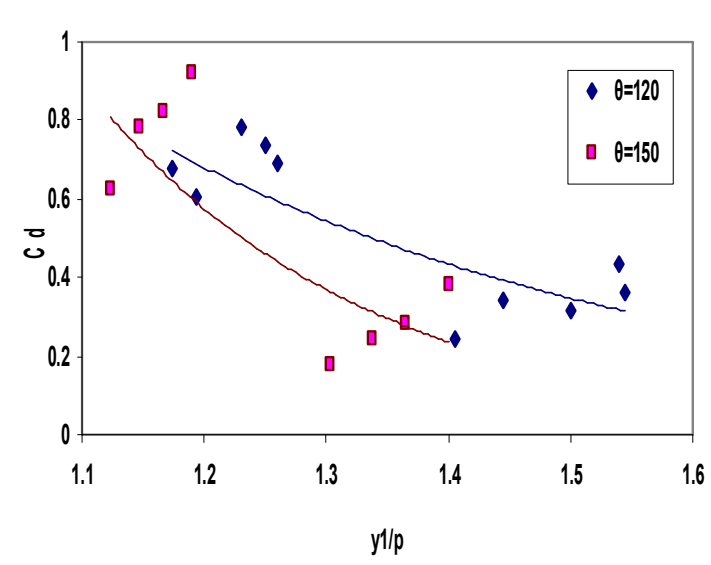

Fig(6) Relation between discharge coefficient (Cd) \& y1/p for obtuse V-notch

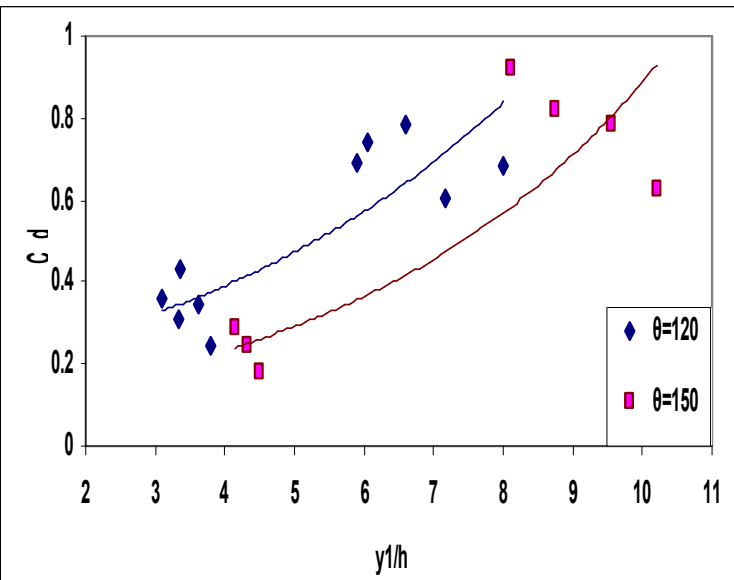

Fig(8) Relation between discharge coefficient (Cd) \& y1/h for obtuse V-notch 

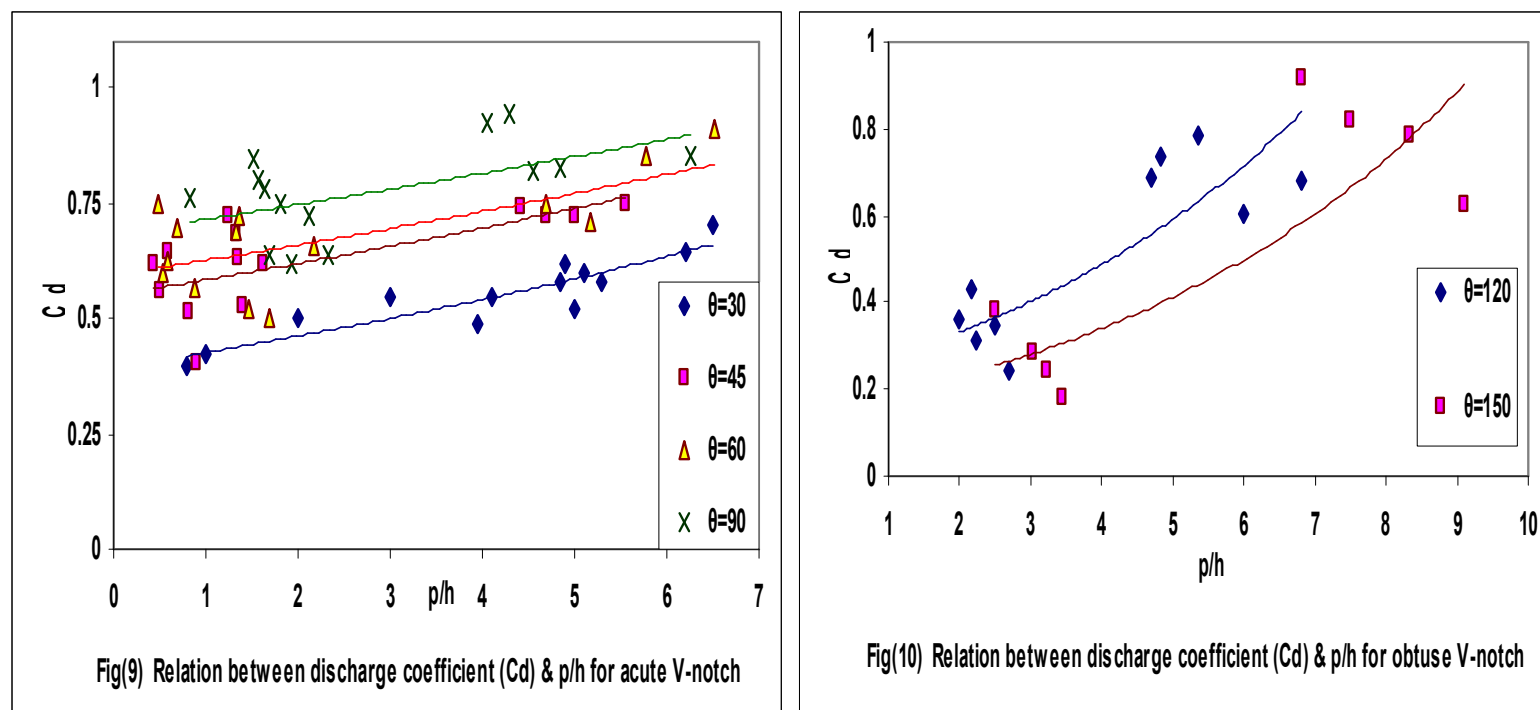

Fig(10) Relation between discharge coefficient (Cd) \& p/h for obtuse V-notch

Table 2: The discharge coefficient range for each degree of $\mathrm{V}$ - notch apex angle

\begin{tabular}{|c|c|}
\hline $\begin{array}{c}\text { V- Notch Apex Angle } \\
\text { (Degree) }\end{array}$ & $\begin{array}{c}\text { Discharge Coefficient } \\
(\mathrm{Cd})\end{array}$ \\
\hline 30 & $0.49-0.79$ \\
\hline 45 & $0.41-0.75$ \\
\hline 60 & $0.50-0.91$ \\
\hline 90 & $0.53-0.92$ \\
\hline 120 & $0.24-0.79$ \\
\hline 150 & $0.20-0.91$ \\
\hline
\end{tabular}

Figure 11 shows the relation between the predicated values of $(\mathrm{Cd})$ from equations ( 8 to 13$)$ and the calculated values of $(\mathrm{Cd})$ with a coefficient of determination $\left(\mathrm{R}^{2}=0.9\right)$. The figure indicates an obvious a good agreement between the calculated and predicated values of $(\mathrm{Cd})$.

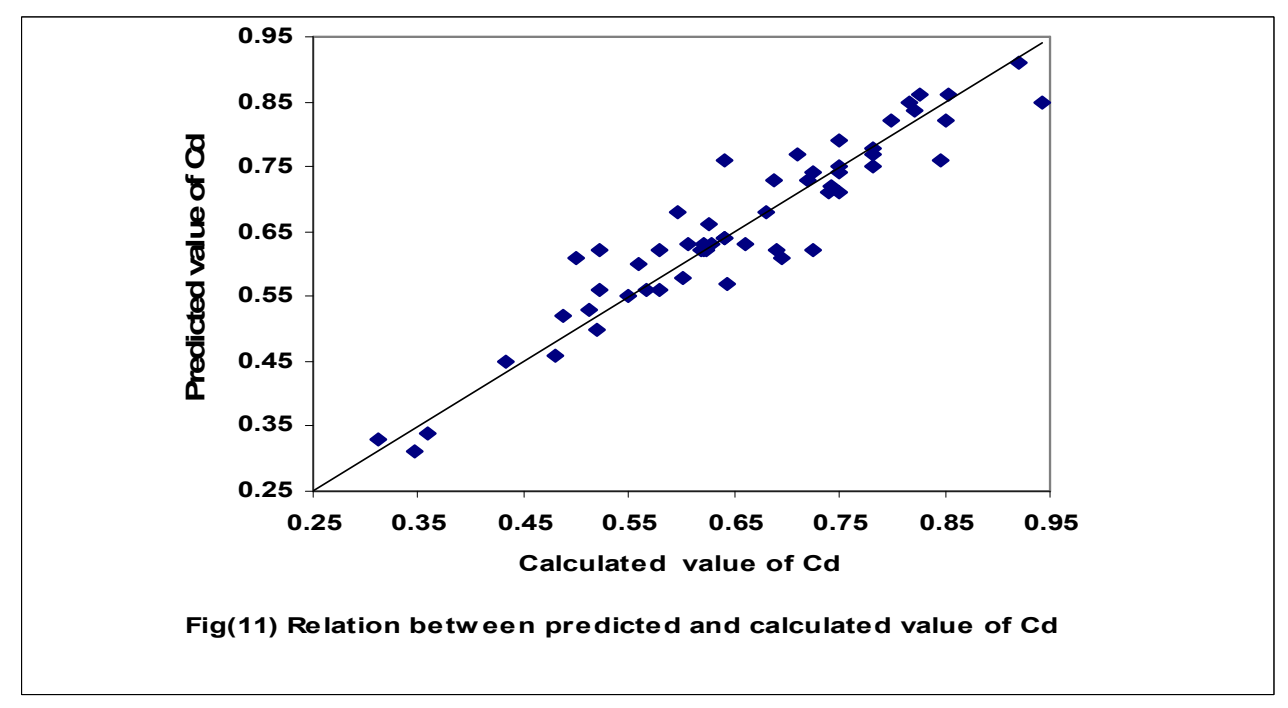




\section{Conclusions:}

The discharge coefficient $(\mathrm{Cd})$ for broad crested $\mathrm{V}$-notch side weir is studied as a function of both hydraulic and geometrical parameters $\left(\mathrm{F} 1, \mathrm{p} / \mathrm{h}, \mathrm{y}_{1} / \mathrm{h}\right.$, and $\left.\mathrm{y}_{1} / \mathrm{p}\right)$ and from analysis of experimental results a mathematical models were developed for different apex angles which enable to determine the side weir discharge coefficient $(\mathrm{Cd})$. The previously developed models give a good estimation when compared with predicated and calculated values of discharge coefficient.

\section{References:}

1- Al Omari, N. K., (2009), "Laboratory Study of the Effect of Branching Angle and the Branching Channel Slope on Flow", M. Sc. Thesis, University of Mousl, Mousl, Iraq.

2-Azimin. H. A. , and N. Rajaratnam , (2009), "Discharge Characteristics of Weir of Finite crest Length", Journal of Hydraulic Engineering, Vol.135,No. 12 .

3-British Standard Institution (BSI) (1965). "Thin- Plate Weirs and Venturi Flumes in method of Method of Measurement of Liquid Flow in Open Channel", Part 4A ,BSI,3681 ,BSI, London.

4-Johenson, M. C. (2000), "Discharge Coefficient Analysis for Flat-Topped and Sharpe Crested Weirs", Irrig. Sci. , 19(3), 133-137.

5-Kumar C. P., and Pathak, S.K. (1987). "Triangular Side Weirs", Journal of Irrigation and Drainage Engineering, ASCE, Vol.113, No. 1, pp 98-105.

6-M. Ghodsion, (2004), "Flow Over Triangular Side Weir ", Scientia Iranica, Vol. 11, Nos. $1 \& 2$.

7-M. Gogus, Z.Defne, and V.Ozkandemir, (2006), "Broad-Crested Weirs With Rectangular Compound Cross Sections", Journal of Irrigation and Drainage Engineering, Vol. 132, No.3. 8-Pinheiro A.N., and Silva I.N., " Discharge Coefficient of Side Weirs Experimental Study and Comparative Analysis of Different Formulas", Proceeding of IAHR, pp.1-8.

The work was carried out at the college of Engg. University of Mosul 